\title{
REACTION OF SOME RUMEN MICRO FLORA TO DIFFERENT SUPPLEMENTARY FEEDS IN RUMEN FISTULATED ANIMALS
}

\author{
Tadessa Daba ${ }^{1}$, Fassil Assefa ${ }^{2}$ and Seyoum Bediye ${ }^{1}$ \\ ${ }^{1}$ Ethiopian Agricultural Research Institute (EIAR), Holetta Research Centre \\ PO Box 31, Holetta, Ethiopia. E-mail: tadessadaba@yahoo.com \\ 2 Department of Biology, Faculty of Science, Addis Ababa University \\ PO Box 1176, Addis Ababa, Ethiopia
}

\begin{abstract}
Ruminant animals lack enzymes to break down fibrous feeds but they harbor microorganisms capable of degrading their feeds. Rumen microbes are affected by feed substrates. The purpose of this study was to evaluate rumen microbial changes as the function of varying supplementary feeds. Two protein supplements (cottonseed cake and tree lucerne) and two energy supplements (wheat bran and molasses) were offered to rumen fistulated oxen of two groups varying in age. The supplements vary mainly in protein and fibre contents. Switch over design was used in the experiment and the oxen were switched to another supplement after one week to avoid the carryover effect. Microbial populations, correlations with feed nutrient composition and enzyme assays in each case were studied and JMP 5.1 computer software was used for the analysis. Both the bacterial and fungal populations were the highest in oxen supplemented with cottonseed cake $(10.7 \times 1011 \mathrm{cfu} / \mathrm{ml}$ bacteria \& $10.8 \times 105 \mathrm{cfu} / \mathrm{ml}$ fungi) in both young and older oxen $(7.4 \times 1010 \mathrm{cfu} / \mathrm{ml}$ bacteria \& $7 \times 105 \mathrm{cfu} / \mathrm{ml}$ fungi), respectively. The total microbial populations were higher in younger groups supplemented with similar supplement than the older groups of oxen and the least microbial count was observed in those supplemented with tree lucerne (Chamaecytisus palmensis). The enzyme activities were also compared and showed significant variations and linear relation with the nutrient compositions of the feeds. A supplement rich in both fibre and protein supported dynamic rumen microbial population and is very important for the production of quality animal products.
\end{abstract}

Key words/phrases: Colony forming unit (cfu), enzyme activities, fibrolytic, optical density

\section{INTRODUCTION}

Ruminant animals are polygastric herbivores, which feed on plants and roughages rich in cellulose and hemicelluloses. These fibrous carbohydrates are derived from $\beta$-linked polymers of glucose and pentose (Bhat et al., 1990). Ruminants lack enzymes capable of breaking down these materials but they harbor microorganisms capable of degrading their feeds in their digestive system particularly in the rumen, reticulum and omasum known collectively as rumen. With the aid of enzymes secreted by the microbes they harness, animals convert highly indigestible and bulk cellulolytic feed resources to highly nutritious and valuable forms of animal products like meat, milk, and other products. The different microorganisms in the rumen are represented by species belonging to different groups of bacteria, fungi and protozoa (Orskov and Rye, 1990).

Microbes in the rumen confer special advantages up on ruminants by digesting or fermenting lignocellulosic sources of energy and make available to them (Bhat et al., 1990; Gordon et al., 2002). Simple and complex carbohydrates (fibres) are digested by rumen microbes and converted into volatile fatty acids (VFAs). These acidic products are substrates to rumen microbes, which in turn can be digested in the intestine as a source of protein for the animals. The volatile fatty acids, which consist mainly of acetic, propionic, and butyric acids, are the primary energy sources for ruminants (Paul and Kamara, 2004). Chenost and Sansoucy (1998) indicated that nutrients required at the tissue level for both maintenance and milk productions are supplied by the end products of rumen fermentation and microbial cell proteins. Flourishing microbial populations can provide $50 \%$ to $80 \%$ of a dairy cow's daily protein requirement and up to $80 \%$ of its energy requirements. The remainder of the cow's nutrients comes from the level of recommended daily nutrients fed (Garrett, 2000).

Rumen contents usually include about $10^{10}-10^{11}$ bacteria $\mathrm{cfu} / \mathrm{ml}$, up to $75 \%$ being associated with food particles (Orskov and Rye, 1990). Among many species of bacteria in the rumen, most of 
them are present at a density of at least $10^{7} / \mathrm{ml}$ (Bhat et al., 1990). The concentration and relative proportions of various classes of rumen organisms vary according to the quality and composition of the diets (Vansoest, 1982). This affects the fermentation end products. The type of fermentation also directly influences the host animal's metabolism, which is also influenced by the type and ratio of the products of particular species of microorganisms. If dairy cows absorb too much propionic acid from their rumens for instance, their blood insulin levels rise, which can seriously affect both the production and the composition of their milk (Duncan et al., 1974). Similarly, in lambs too, high proportion of propionic acid, relative to the other fatty acids, results in the deposition of undesirable branched chain soft fat (Duncan et al., 1974).

The rumen habitat changes in relation to the quality of diet. This in turn, changes the metabolic activity of the microbial inhabitants (Findlay, 1998). Any excess feeding or abuse can rapidly alter the normal microfloral population; leading to serious and often life threatening cases. Understanding the functions of rumen microorganisms enable to modify these functions for more efficient animal production (Chesworth, 2004). In Ethiopia, most of the hitherto works were focused on the evaluation of the feeding qualities of indigenous and exotic forage species (Getnet Assefa et al., 2003; Seyoum Bediye et al., 2004) with particular emphasis on their dry matter (DM), crude protein (CP), crude fibre (CF), total mineral (ash) contents, digestibility and feeding values in milk and meat production (Varvikko and Khalilli, 1993; Tesfaye Wondimu et al., 2001; Seyoum Bediye et al., 2004). Although several researches at International Livestock Research Institute (ILRI) were conducted on the microbiology of detoxification of anti-nutritional factors in browse feed supplements (Odenyo et al., 1997; Odenyo et al., 1999; Misrak Kebede, 2000; Eden Efrem, 2002), there was little work on the effect of feed on microbial density of (rumen fistulated) animals in relation to changes in their diet.

Thus, it is imperative to study the relationship between potential and commonly used ruminant feed supplements and rumen microbes with varying animal feeds, which have direct impact on the quantity and quality of the final products. This also helps for the optimum utilization of feed supplements and has an implication on the production of the required products with presumed quality by enhancing the efficiency of rumen microbes. The purpose of the present study was, therefore, to evaluate rumen microbial density and diversity as the function of varying supplementary feeds and age of animals.

The abbreviations used in this paper were: Acid Detergent Fibre; $A D F$, crude fibre; $\mathrm{CF}$, crude fibre; $\mathrm{CFU}$, colony forming units; $\mathrm{CP}$, crude protein; $\mathrm{DM}$, dry matter; DOMD, dry organic matter digestibility; FAO/IAEA, food and agriculture organization/international atomic energy agency; Kcal, kilo calorie; ME, metabolizable energy; MJ, mega joule; $\mathrm{ml}$, milliliter; $\mathrm{mM}$, milimolar; Mol. $\mathrm{Wt}$, molecular weight; NA, nutrient agar; NDF, neutral detergent fibre; $\mathrm{nm}$, nanometer; $\mu \mathrm{m}$, micrometer; $\mu \mathrm{mol}$, micromole; OD, optical density; PDA, potato dextrose agar; TCA, trichloroacetic acid; VFA, volatile fatty acids; DNS, dinitrosalisalic solution; PNPP, p-nitrophenol palmitate.

\section{MATERIALS AND METHODS}

\section{Study site}

The study was conducted at Holleta Agricultural Research Centre, which is found at $28 \mathrm{~km}$ West of Addis Ababa with typical highland climatic conditions and altitude of 2400 m.a.s.l. Animal based activities; rumen fluid sampling, primary culture and subcultures were undertaken at Holetta, Animal Nutrition laboratory. Microbial characterizations, enzyme assays and population density/optical density (OD) measurements were undertaken at Applied Microbiology Laboratory, Department of Biology, Addis Ababa University (AAU).

\section{Experimental feeds}

The animals were fed a basal diet of native hay. Two protein rich supplementary feeds namely, tree lucerne (Chamaecytisus palmensis) and cottonseed cake and two energy supplements wheat bran and molasses were used. Native hay was offered adlibtum and the supplementary feeds were fed at recommended levels: wheat bran $3 \mathrm{~kg} /$ day (Tesfaye Wondimu et al., 2001), Molasses $1 \mathrm{~kg} / \mathrm{d}$ (Garrysmith, 1987), Cottonseed cake 3kg/d (Njoya, 1996) and wilted tree lucerne $7 \mathrm{~kg} / \mathrm{d}$ (Varvikko and Khalilli, 1993). The nutritive values of the experimental feeds, which greatly vary in protein, fibre and energy compositions, were presented in Table 1. 
Table 1. Nutritive values of the experimental feeds (Seyoum, et al., 2007).

\begin{tabular}{|c|c|c|c|c|c|c|c|c|c|c|}
\hline Feed & DM & Ash & $\mathrm{CP}$ & NDF & ADF & Hemi & Lignin & DOMD & ME & Category \\
\hline Wheat bran & 93.3 & 4.7 & 18.9 & 53.1 & 8.3 & 44.8 & & 87.1 & 13.0 & Energy supplement \\
\hline Molasses & 27.7 & & 3.3 & - & - & - & - & 99.7 & 14.96 & Energy supplement \\
\hline Tree lucerne & 40 & 4.9 & 18.0 & 64.4 & 42.8 & 22.7 & 7.8 & 71.0 & 10.7 & Protein supplement \\
\hline Cottonseed cake & 92.5 & 7.5 & 26.9 & 65.1 & 31.0 & 34.1 & 6.7 & 59.0 & 8.9 & Protein supplement \\
\hline
\end{tabular}

Note: $\mathrm{DM}=$ Dry matter, $\mathrm{CP}=$ Crude protein, $\mathrm{NDF}=$ Neutral Detergent Fibre, $\mathrm{ADF}=$ Acid Detergent Fibre, Hemi= Hemicellulose, $\mathrm{DOMD}=$ Dry Organic Matter Digestibility, ME= Metabolizable Energy

\section{Experimental animals}

Six rumen fistulated or cannulated oxen were used for the experiment. Four of them were young ( $\sim 8$ years) and two were old ( 15 years) to evaluate the age attributes of the experiment. Each one of them was assigned to different experimental feed supplements. Switch over design was used because of the limited number of rumen fistulated experimental animals available. One-week adaptation period prior to data collection was taken to each of the supplementary feeds to acclimatize the experimental animals and let appropriate microbes colonize the rumen both at the beginning and in between the switching over times (Tesfaye Wondimu et al., 2001). After actual data collection was undertaken for each supplementary feeds and one-week break was used in between the switch over to avoid the carry over effect of the previous supplements. The same procedure was repeated until both age groups of all the experimental oxen received all the supplements. The experiment was conducted between December 2006 and February 2008.

\section{Media preparation}

Nutrient Agar (Himedia Laboratories) was used for bacterial isolation and enumeration with benomyl (benlate) fungicide. For the isolation of fungi, Potato Dextrose Agar (PDA) was used with addition of $0.1 \mathrm{~g}$ chloramphenicol antibiotic. De Mann Rogosa Sharp agar (MRS) was used for the identification of lactic acid bacteria (LAB). All the media used were enriched with $5 \mathrm{ml}$ mineral 1 solution and $0.4 \mathrm{ml}$ mineral 2 solutions (Tilley and Terry, 1963). Table 2 shows the compositions of mineral 1 and 2 solutions.

\section{Rumen samples}

The rumen fluid samples were taken every 3 hours after feeding directly through the cannulae into sterilized thermo flask to maintain the temperature at $39^{\circ} \mathrm{C}$ (Moharrery and Das, 2001). About $10 \mathrm{ml}$ of the rumen digest and fluid samples from each ox was then gently squeezed by new cheesecloth into sterilized beaker with stable temperature in water bath with continuous supply of $\mathrm{CO}_{2}$ from cylinder.

Table 2. Compositions of mineral solutions (Tilley and Terry, 1963).

\begin{tabular}{lc}
\hline Chemicals & Amount per litter \\
\hline Mineral 1 solution & \\
$\mathrm{K}_{2} \mathrm{HPO}_{4}$ & $0.6 \mathrm{~g}$ \\
Mineral 2 solution & \\
$\mathrm{K}_{2} \mathrm{HPO}_{4}$ & $0.6 \mathrm{~g}$ \\
$\left(\mathrm{NH}_{4}\right)_{2} \mathrm{SO}_{4}$ & $0.6 \mathrm{~g}$ \\
$\mathrm{NaCl}$ & $1.2 \mathrm{~g}$ \\
$\mathrm{MgSO}_{4} .7 \mathrm{H}_{2} \mathrm{O}$ & $0.245 \mathrm{~g}$ \\
$\mathrm{CaCl}_{2} .2 \mathrm{H}_{2} \mathrm{O}$ & $0.159 \mathrm{~g}$ \\
\hline
\end{tabular}

\section{Viable colony count}

Serial dilution was undertaken by transferring $1 \mathrm{ml}$ of the rumen fluid to $9 \mathrm{ml}$ sterilized distilled water with successive dilutions up to $10^{-11}$. The samples from $10^{-3}-10^{-6}$ were PDA and samples from $10^{-6}-10^{-11}$ were inoculated into Nutrient agar (NA) and de Mann Rogosa Sharp agar (MRS, OXOID) the media prepared for bacteria with continuous flushing of $\mathrm{CO}_{2}$ (Paul and Kamara 2004; Orskov and Rye 1990). The anaerobically inoculated samples were tightly packed with parafilm and aluminium foil and immediately put in anaerobic jar with candle and incubated at $39^{\circ} \mathrm{C}$ 3days for bacteria and 5 days for rumen fungi.

\section{Identification of rumen microbes}

After isolation and subculturing, the pure cultures were tightly packed in anaerobic jar and preserved at $4^{\circ} \mathrm{C}$ for cultural characteristics and gram reaction. The isolates were inoculated into the appropriate media and checked for their colony characteristics (gram reaction, colour, shape, etc). Then the rumen bacteria were identified based on Bergey's manual (Bergey, 1984) and previous findings of Findlay (1998). For rumen fungi, laboratory manual of mycology 
(Alexopoulus and Beneke, 1968) and pervious findings of Wina et al. (2006) and Akin and Borneman (1990) were used for the identification.

\section{Enzyme assay}

Amylase

Amylase activity was determined through measuring the reducing sugar by the dinitrosalicylic (DNS) method (Jamieson et al., 1968). The enzyme activity was carried out at $40^{\circ} \mathrm{C}$, using $1.0 \%(\mathrm{w} / \mathrm{v})$ soluble starch dissolved in $0.2 \mathrm{M}$ tris$\mathrm{HCl}$ buffer ( $\mathrm{pH} 7)$ as substrate. The anaerobically preserved rumen fluid sample was centrifuged at $10,000 \mathrm{rpm}$ for 5 minutes and the supernatant was taken as a crude enzyme source. In this method, $0.9 \mathrm{ml}$ of starch solution was taken and $0.1 \mathrm{ml}$ of crude enzyme source was added and incubated at $40^{\circ} \mathrm{C}$ for 10 minutes. The reaction was stopped by 2 $\mathrm{ml}$ DNS reagent followed by boiling for 5 minutes. Absorbance was measured using spectrophotometer (Jenway 6405, Germany) at $540 \mathrm{~nm}$ against a reagent and an enzyme blank. An enzyme unit (U) is the amount that releases1 $\mu$ mole of reducing sugar that release equivalent to glucose per minute.

\section{Cellulase}

To determine cellulase activity, the same method was used as amylase except carboxymethyl cellulose (CMC) was used as substrate. CMC $(0.5 \mathrm{~g})$ was dissolved in $25 \mathrm{ml}$ distilled water through gentle heating and added to $25 \mathrm{ml}$ of $0.2 \mathrm{M}$ sodium acetate buffer at $\mathrm{pH} 5$. The anaerobically preserved rumen fluid sample was centrifuged at 10,000 rpm for 5 minutes and the supernatant was taken as a crude enzyme source. $0.9 \mathrm{ml}$ the substrate was taken and $0.1 \mathrm{ml}$ of crude enzyme source was added on it and incubated at $40^{\circ} \mathrm{C}$ for 10 minutes. The reaction was stopped by $2 \mathrm{ml}$ DNS reagent followed by boiling for 5 minutes. Absorbance was measured on spectrophotometer at $540 \mathrm{~nm}$ against a reagent and an enzyme blank.

\section{Protease}

Protease activity was assayed according to the method described by Amare Gessesse and Berhanu Gashe (1997) using casein substrate. The anaerobically preserved rumen fluid sample was centrifuged and the supernatant was taken as a crude enzyme source. To $450 \mu \mathrm{l}$ of $1 \%$ casein, $50 \mu \mathrm{l}$ of enzyme source was added. It was incubated for 30 minutes at $50^{\circ} \mathrm{C}$, and then $500 \mu \mathrm{l}$ of $10 \%$ trichloroacetic acid (TCA) was used to stop the reaction. After incubation for 20 minutes at room temperature, it was centrifuged at 10,000 rpm for 5 minutes and $500 \mu \mathrm{l}$ of the supernatant was taken and $2.5 \mathrm{ml}$ of $0.5 \mathrm{M} \mathrm{Na}_{2} \mathrm{CO}_{3}$ was added on it. Finally, $500 \mu \mathrm{l}$ of $1: 10$ diluted $1 \mathrm{~N}$ folin ciocalteaus's phenol reagent was mixed and the result was measured at 660nm (Jenway 6405). One unit of protease activity (U) is the amount of enzyme, which resulted in the release of $1 \mu \mathrm{g}$ amino acid equivalent to tyrosine per minute.

\section{Lipase}

Lipase activity was determined using $\mathrm{p}$ nitrophenol palmitate (PNPP, sigma USA) as a substrate. A stock solution of PNPP (20nM) was prepared using isopropanol. Working substrate solution was prepared by diluting the PNPP stock solution 1:20 $50 \mathrm{nM}$ Tris $\mathrm{HCl}$ buffer containing $0.1 \%$ gum Arabic and $0.4 \%$ Triton X-100 and used also as a standard. The anaerobically preserved rumen fluid sample was centrifuged at 10,000 rpm for 5 minutes and the supernatant was taken as a crude enzyme source. Lipase activity was measured by mixing $0.9 \mathrm{ml}$ of working substrate solution and $0.1 \mathrm{ml}$ enzyme source. Absorbance was measured after 30 minute at $410 \mathrm{~nm}$ (Jenway 6405). For the quantification of enzyme unit, an extinction coefficient of $14,080 / \mathrm{M} \mathrm{cm}$ was taken for PNPP. One unit of lipase activity was defined as the amount of enzyme, which releases $1 \mu \mathrm{mol}$ of paranitrophenol per minute. The appearance of a yellow colour indicates lipase activity and the release of PNPP (Amare Gessesse et al., 2003).

All data was analyzed using multiple mean comparison of JMP computer software.

\section{RESULTS}

\section{Viable counts}

The viable rumen bacterial and fungal colonies were found to vary in animals offered different supplements. The highest bacterial count was recorded from rumen of oxen fed on cottonseed cake $\left(1.07 \times 10^{11} \mathrm{cfu} / \mathrm{ml}\right)$ followed by molasses $\left(7.5 \times 10^{10} \mathrm{cfu} / \mathrm{ml}\right)$.

\section{Bacteria}

There was statistically significant $(p<0.05)$ difference in viable bacterial colony count among all the feed supplements except wheat bran, which didn't show significant difference from tree lucerne and molasses fed ones. There was statistically significant $(\alpha=0.05)$ difference in bacterial populations amongst all supplementary feeds in 
older oxen except molasses and cotton seed cake, which didn't display significant difference. The highest colony count was recorded in molasses fed oxen and the least was in those fed on tree lucerne (Table 3).

Table 3. Rumen bacterial population comparisons based on supplementary feeds.

\begin{tabular}{lll}
\hline Supplement & $\begin{array}{l}\mathrm{cfu} / \mathrm{ml} \text { in young oxen } \\
(8 \text { years) }\end{array}$ & $\begin{array}{l}\mathrm{cfu} / \mathrm{ml} \text { in olds } \\
\text { oxen }(15 y e a r s)\end{array}$ \\
\hline Wheat bran & $6.85 \times 10^{10 \mathrm{BC}}$ & $4.3 \times 10^{10 \mathrm{~B}}$ \\
Molasses & $7.56 \times 10^{10} \mathrm{~B}$ & $8.2 \times 10^{10 \mathrm{~A}}$ \\
Cotton seed cake & $1.07 \times 10^{11 \mathrm{~A}}$ & $7.4 \times 10^{10 \mathrm{~A}}$ \\
Tree lucerne & $5.19 \times 10^{10 \mathrm{C}}$ & $3.1 \times 10^{10 \mathrm{C}}$ \\
\hline
\end{tabular}

Note: Superscripted letters indicate significance of differences with in similar age groups.

\section{Bacterial colony counts between age groups}

In all the supplements, colony counts were significantly $(p<0.05)$ higher in younger oxen than in older ones except in case of molasses fed animals, where there was no significant variation in rumen bacterial population with age.

\section{Fungi}

With regard to rumen fungal count, cottonseed cake showed the highest $1.8 \times 10^{6}$; whereas molasses showed the least fungal population $6.27 \times 10^{5}$ in younger oxen. There was no statistically significant $(p<0.05)$ difference between wheat bran and molasses fed animals. Wheat bran was characterized by a slight lower number of fungal counts than the cottonseed cake and tree Lucerne (Table 4). In older oxen the highest fungal count was observed in cottonseed cake fed animal whereas the least fungal colony count was recorded in those fed on molasses. There was significant $(p<0.05)$ difference among all supplements except wheat bran and tree lucerne.

Table 4. Rumen fungal population comparisons based age and supplementary feeds.

\begin{tabular}{lll}
\hline Supplement & $\mathrm{cfu} / \mathrm{ml}$ in young oxen & $\begin{array}{l}\mathrm{cfu} / \mathrm{ml} \text { in olds } \\
\text { oxen }\end{array}$ \\
\hline Wheat bran & $9.43 \times 10^{5 \mathrm{AB}}$ & $5.1 \times 10^{5 \mathrm{~B}}$ \\
Molasses & $5.13 \times 10^{5 \mathrm{AB}}$ & $4.3 \times 10^{5 \mathrm{C}}$ \\
Cotton seed cake & $1.08 \times 10^{6 \mathrm{~A}}$ & $7 \times 10^{5 \mathrm{~A}}$ \\
Tree lucerne & $6.27 \times 10^{5 \mathrm{~B}}$ & $5 \times 10^{5 \mathrm{~B}}$ \\
\hline
\end{tabular}

Note: Superscripted letters indicate significance of differences with in similar age groups.

\section{Fungal colony count between age groups}

With regard to fungal colony, they were significantly $(p<0.05)$ higher in younger ones as compared to the older oxen offered similar supplementary feed.

\section{Isolation of rumen bacteria}

In this study 12 taxonomic groups of bacteria were isolated from oxen. They were dominated by gram negative bacteria ( 8 isolates) followed by gram positive bacteria (4 isolates). The gram positive bacteria were mostly cocci with whitish colonies except $\mathrm{B}_{4}$ which was rod shaped bacterium. On the contrary, the gram negative bacteria were rod/bacilli, cocci and spherical in shape. The 12 isolates were tentatively classified in to 12 genera (Table 5).

Table 5. Isolated rumen bacteria from oxen offered different feed supplements.

\begin{tabular}{|c|c|c|c|c|c|}
\hline Code & $\begin{array}{l}\text { Gram } \\
\text { reaction }\end{array}$ & Colony characteristics & Cell Shape & Cellular arrangement & $\begin{array}{l}\text { Genera (possible } \\
\text { identity) }\end{array}$ \\
\hline $\mathrm{B}_{1}$ & Negative & yellowish creamy & simple rod with rounded ends & Single rod & Bacteriodes \\
\hline $\mathrm{B}_{2}$ & Negative & creamy white, fast grower & rods & Single rod & Enerobacter \\
\hline $\mathrm{B}_{3}$ & Negative & cloudy white & rod/crescent-shaped & Single crescent & Selenomonas \\
\hline $\mathrm{B}_{4}$ & Positive & whitish yellow & long rods, slender & Single long rods & Lactobacillus \\
\hline $\mathrm{B}_{5}$ & Negative & yellowish, slow grower* & spherical & irregular clusters & Succinimonas \\
\hline $\mathrm{B}_{6}$ & Positive & creamy white & cocci & Chained cocci & Streptococcus \\
\hline $\mathrm{B}_{7}$ & Negative & creamy white & rod, pointed ends & Single rod & Fusobacterium \\
\hline $\mathrm{B}_{8}$ & Positive & cloudy white & large spherical & in pairs spherical & Leuconostoc \\
\hline B 9 & Positive & yellowish, slow grower* & cocci & Single/ pairs/ tetrads & Pediococcus \\
\hline $\mathrm{B}_{10}$ & Negative & whitish creamy & large spherical & Clusters spherical & Methanosarcina \\
\hline $\mathrm{B}_{11}$ & Negative & whitish & small cocci & Single cocci & Ruminococcus \\
\hline $\mathrm{B}_{12}$ & Negative & whitish brown & curved short spiral & singlespiral & Butyrivibrio \\
\hline
\end{tabular}

Note: $\quad$ * Slow growers were those which required more than three days for growth. 
The frequency distribution of the different microflora of the rumen from oxen fed different supplements showed significant differences. Table 6 showed that cottonseed cake harboured $75 \%$ of all the isolates followed by wheat bran $(50 \%)$ and molasses (50\%). The least bacterial diversity was recorded in tree lucerne fed oxen $(33 \%)$. The dominant bacterial isolates from animals fed on wheat bran were the gram negative rod shaped Bacteriodes (2/6) followed by Ruminococcus, which covered of all the isolates. The lowest proportion was found to be gram positive cocci, streptococcus. Butyrivibrio spp. were found to dominate in molasses fed oxen and Ruminococcus encountered rarely. The gram-positive long rods, Lactobacillus predominated the rumen bacteria in tree lucerne fed animals. The majority of bacteria isolated from tree lucerne fed animals were gram positive while gram negatives were dominant in animals offered other supplements. Ruminococcus was the ubiquitous isolate which was found in all the supplements followed by Selenomonas, Lactobacillus and Streptococcus while Enterobacter, Succinimonas, Leuconostoc and Methanosarcina were found only in oxen fed on single supplements.

Table 6. Isolated rumen fungi from all oxen offered different feed supplements.

\begin{tabular}{lll}
\hline Code Colony characteristics & Fungal isolates \\
\hline F1 & $\begin{array}{l}\text { Highly branched mycelium } \\
\text { (rhizoid), with dark sporangia }\end{array}$ & $\begin{array}{l}\text { Phycomycetes } \\
\text { (Caecomyces spp.) }\end{array}$ \\
F2 & $\begin{array}{l}\text { branched hyphea with } \\
\text { flagellated zoospores }\end{array}$ & $\begin{array}{l}\text { Chytridiomycetes } \\
\text { (Chytridium spp.) }\end{array}$ \\
F3 & $\begin{array}{l}\text { Slight yellowish, filamentous } \\
\text { Fast grower, highly budding }\end{array}$ & $\begin{array}{l}\text { Neocallimastix } \\
\text { (Sells }\end{array}$ \\
& & (Saccharomyces spp.) \\
\hline
\end{tabular}

\section{Isolation of rumen fungi}

Apart from the bacteria four groups of fungi were also isolated from the rumen of the tested oxen. Most of the fungi were lower fungi Phycomycetes and Chytridiomycetes except yeast, which was classified in Ascomycetes (Hemiascomycetes). The relative proportions of the rumen fungal isolates were not as diverse as they were for bacteria. There were only few rumen fungi isolated from the rumen samples of animals fed on different feed supplements. They rather vary in density and proportion than in diversity among the supplements (Table 4).

With regard to the distribution of the fungal isolates in relation to the feed type, Caecomyces and Neocallimastix were found in 3 out of 4 tested supplements followed by Chytridium. Caecomyces spp. were dominant in wheat bran and cottonseed cake supplemented oxen. Caecomyces and Neocallimastix were the only fungi isolated from tree lucerne fed oxen and yeast was found only in high-energy supplements (molasses and wheat bran) (Table 6).

\section{Correlation between microbial density and nutrient composition of feeds}

Rumen fungal population was highly correlated with the fibre contents of feeds than bacteria. Both rumen bacteria and fungi were better correlated with the protein composition of feeds than with fibre. Both rumen bacteria $\left(\mathrm{r}^{2}<0.3, \mathrm{p}<0.05\right)$ and fungi $\left(r^{2}<0.4, p<0.05\right)$ were poorly correlated with metabolizable energy (ME) contents of feeds. Rumen fungi were also found to be more affected by the ME compositions than do the rumen bacteria.

\section{Rumen enzyme assays}

\section{Amylase}

The highest amylase activity was recorded in molasses and wheat bran fed younger oxen while the least was displayed in tree lucerne fed older animals (Fig. 1). There were no significant difference $(p=0.01)$ between wheat bran and molasses; cottonseed cake and tree lucerne fed oxen. The amylase activities were significantly higher in younger oxen than the older ones fed on similar supplements.

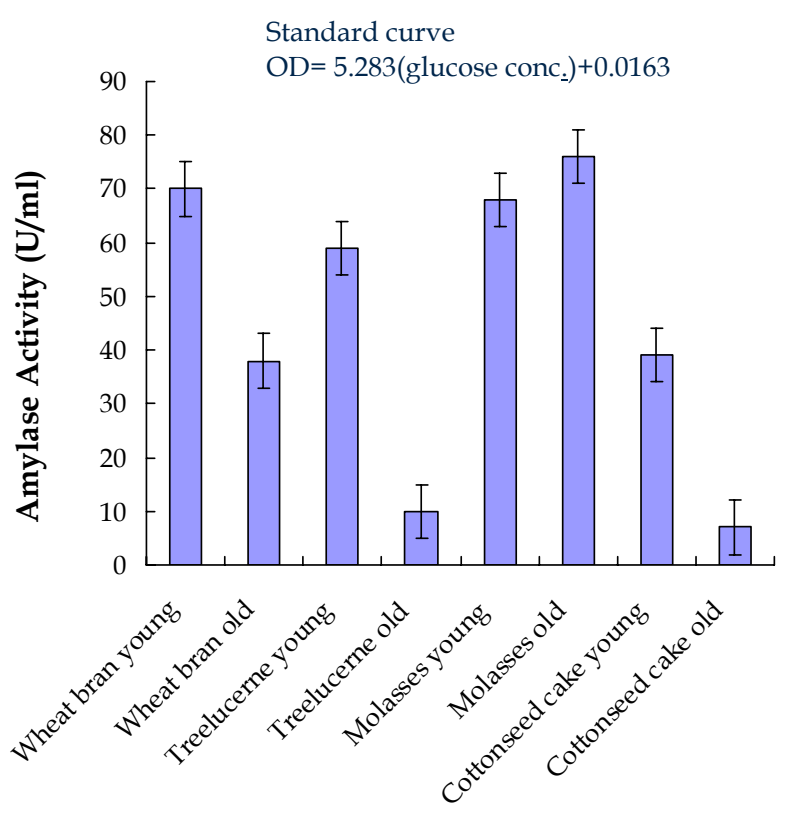

Feed Supplements

Fig. 1. Comparison of amylase activities against feed supplements and age of oxen. 


\section{Cellulase}

The cellulase activity was the highest in wheat bran but significantly $(p<0.05)$ different only from those supplemented with molasses (Fig. 2). There is no variation because age except in the case of molasses, where it is unusually higher in the older oxen.

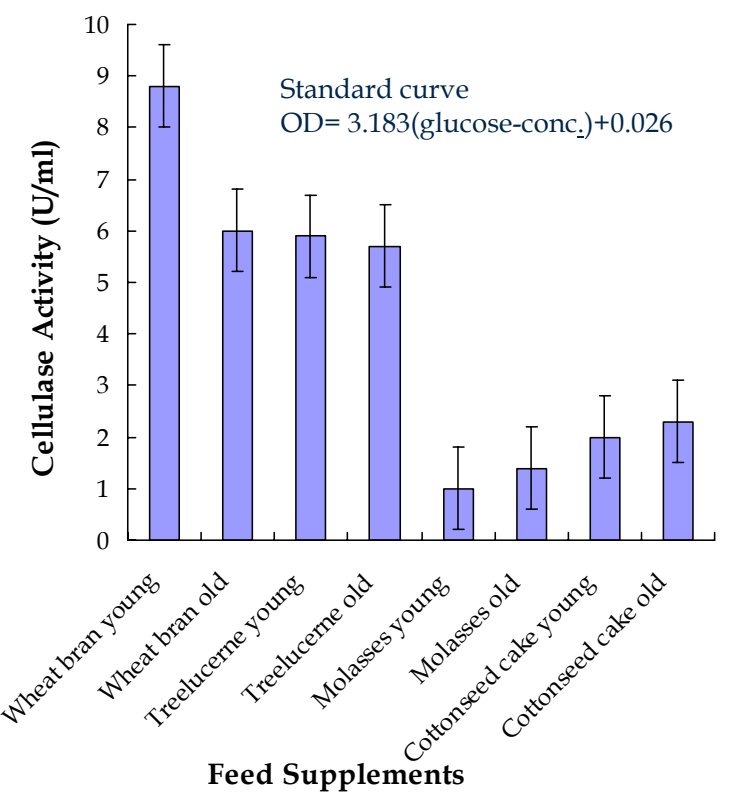

Fig. 2. Comparison of cellulase activities against feed supplements and age of oxen.

\section{Protease}

In all the supplements, the highest protease activities were detected relative to other enzymes in the rumen. Protease activity was the highest $(p<0.05)$ in oxen offered cottonseed cake supplement but is not significantly higher than those fed on tree lucerne (Fig. 3). The least protease activity was observed in case of molasses supplemented oxen. There was no difference $(\mathrm{P}<0.05)$ between age groups except in case of cottonseed cake supplemented ones, where it is higher in younger oxen.

\section{Lipase}

Highest lipase activity was observed in oxen supplemented with molasses and is significantly $(\alpha=0.05)$ the highest of all. Wheat bran is also significantly higher than others and the least lipase activity was seen in oxen offered tree lucerne (Fig. 4). The variation with animal age group was significant in all cases with higher activities in younger animals.

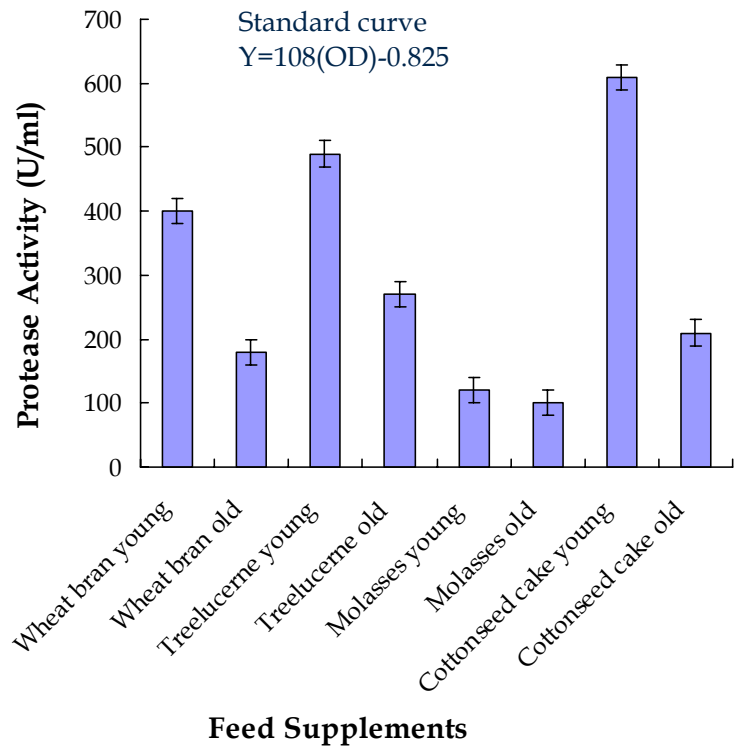

Fig. 3. Comparison of Protease activities against feed supplements and age of oxen.

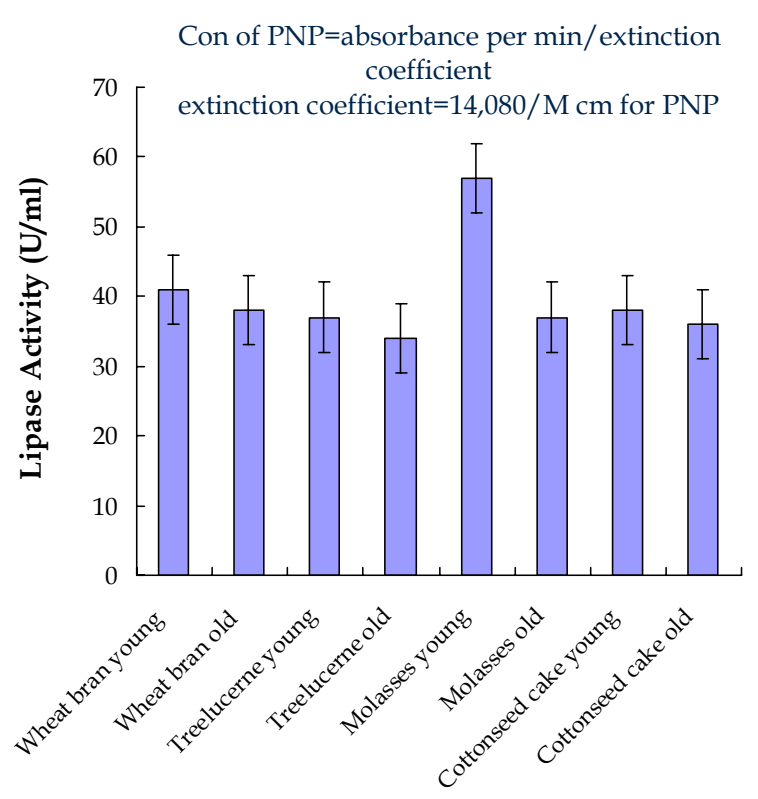

Feed Supplements

Fig. 4. Comparison of lipase activities against feed supplements and age of oxen.

\section{DISCUSSION}

The rumen microbial density varied $(p<0.05)$ greatly based on the nutrient composition of feeds particularly the protein and fibre contents. Vansoest (1982) also indicated that the concentration and relative proportions of various 
classes of rumen organism vary according to the quality and composition of the diets. The maximum number of bacterial colonies found in this study was $10.7 \times 10^{10} \mathrm{cfu} / \mathrm{ml}$ bacteria and 10.8 $\mathrm{x} 10^{5} \mathrm{cfu} / \mathrm{ml}$ fungi. In the same way, Findlay (1998) reported about $10^{10}$ to $5 \times 10^{10} \mathrm{cfu} / \mathrm{ml}$ of rumen bacteria. Similarly, $10^{10}-10^{11} \mathrm{cfu} / \mathrm{ml}$ of bacteria and $10^{4} \mathrm{cfu} / \mathrm{ml}$ of fungal colonies were reported by Bhat et al. (1990) and Paul and Kamara (2004) respectively. The highest microbial population was found in animals fed on cottonseed cake, which contains high protein and fibre. The microbial responses to high energy feed like molasses was less.

The rumen microbes' first-limiting nutrient is nitrogen. However, if forage crude protein is good, then rumen microbes might benefit from an energy source (Wahlberg, 1999). Gordon et al. (2002) also conducted studies on mixtures of alfalfa, grass, and heather (a dwarf shrub) and compared the ability of the rumen microflora to digest the mixtures of substrates and found good response in alfalfagrass mixture. Among five rations varying in the proportions of roughage, concentrate, energy and protein contents fed to sheep, crude protein enhanced microbial population and this could change the pattern of enzymes in the rumen (Moharrery and Das, 2001).

The least rumen bacterial count was recorded in tree lucerne fed oxen even though it is good in nutrient composition (Table 1). This may be attributed to its anti nutritional factor contents like tannin and saponin. Multipurpose trees like tree lucerne contains high proportion of tannin and saponin (Eden Efrem, 2002). Similarly, Odenyo et $a l$, (1997) found that tannin inhibits rumen bacteria particularly cellulolytic bacteria. Moreover, saponin showed its inhibitory effect on rumen protozoa and microbial fermentation in the ruminants (Wallace, 1994). Both rumen bacterial and fungal populations were found to be higher in younger oxen than the older ones supplemented with similar feeds.

Much of the previous studies (Akin and Borneman, 1990; Orskov and Rye, 1990) were on rumen microbial differences in infant calves and adult animals. The reason why rumen microbial mass greatly declines in older age wasn't described in literatures. The rumen bacteria are weakly correlated with the fibre contents of feeds. Rumen viable fungal colonies were highly correlated with both protein and fibre compositions of the feeds offered to animals than bacteria. This implies that rumen bacteria were less sensitive to the changes in the fibre and protein composition of feeds. This may be because bacteria are more versatile in metabolism and could synthesize the required nutrients from other sources than do rumen fungi. FAO/IAEA (1989) and Joblin et al. (1990) also reported that rumen fungi were predominant in fibrous feeds. The increased fungal populations occurred with alfalfa (protein rich) and Bermuda grass (fibrous) diets.

The influence of diet on rumen fungi might occur because of direct effects such as supplying a growth factor or because of indirect effects by influencing competing organisms (Joblin et al., 1990). This indicates that rumen fungi are better responsible for the digestion of fibrous feeds because most fungi produce exogenous enzymes and also able to physically penetrate plant cell wall (Wina et. al., 2006). Both rumen bacterial and fungal populations were better correlated with the protein compositions of feeds than with fibre contents as also described by Wahlberg (1999) and Gordon et al. (2002).

Both rumen bacteria and fungi had weaker correlation with ME (metabolizable energy) contents of the supplementary feeds (Tables 1, 3 and 4). This indicates that rumen microbes are not very sensitive to the changes in the energy compositions of feeds offered to animals. This may be because they are capable of generating the required amount of energy from other feed nutrients as far as they get sufficient protein as explained by Wahlberg (1999). Microbial diversity in the rumen significantly varied with feed nutrient composition.

Among the identified rumen bacteria, Bacteriodes and Ruminococcus were found to be dominant in wheat bran and cottonseed cake, which are rich in fibre. There was similar report by Findlay (1998). Butyrivibrio and Pediococcus were predominated in rumen of molasses supplemented oxen. In tree lucerne supplement, which is high in tannin content gram-positive bacteria were dominant. Similarly Wallace (1994) found that the major tannin tolerant bacteria identified were gram positive. This may indicate that the negative action of anti-nutritional factors is on the cell wall of rumen bacteria.

Significant variation in the enzyme activities were found based on the nutrient compositions of feeds supplemented to the animals. Rations varying in the proportions of roughage, concentrate, energy and protein contents affected microbial population and changed the pattern of enzymes in the rumen (Moharrery and Das, 2001). In oxen supplemented with molasses, which is the 
least in protein and fibre contents, showed the least cellulase and protease (Fig. 2 and Fig. 3) activities but good lipase (Fig. 4) and the highest amylase (Fig. 1) activities because of its high energy content. On the contrary, in cottonseed cake offered animals there were higher cellulase (Fig. 2) and protease (Fig. 3) activities as it contains high fibre and protein. Wheat bran, which is high in fibre and starch compositions showed good amylase and cellulase activities. In general, the enzyme activity assays indicated linear relations with the proportions of the feed nutrient compositions. In almost all the cases, the enzyme activities were less in the older oxen supplemented with similar feeds. Butyrivibrio was dominant in molasses offered animals where the highest amylase activity was recorded and thus may be good candidate for amylase production. In cottonseed cake fed animals Bacteriodes spp. were dominant and may be good producer of protease and cellulase. In all the treatments, the activities of protease were higher than other enzymes (Fig. 3), which indicates that most of the rumen organisms able to produce protease and utilize the ample protein sources in the rumen.

\section{CONCLUSIONS}

Feeds containing high protein and fibre favour rumen microbial population dynamics than feeds with high-energy source. High anti nutritional factors (e.g., tannin, saponin, etc.) hinder rumen microbial growth but gram-positive bacteria better resist these anti nutritional factors. Bacteriodes, and Ruminococcus dominate rumen microbial population in roughage feeds. Butryvibrio are dominant in feeds containing easily soluble carbohydrates. Rumen fungi are more responsive to the fibre and protein compositions of feeds. Further molecular based isolation study is required to identify and select the rumen microbial species responsible for the production of given volatile fatty acids. Both rumen bacteria and fungi are more sensitive to the protein contents of feeds. Rumen microbial population and enzyme activities decline in older age. The reason why this happens also needs further investigation.

\section{ACKNOWLEDGEMENTS}

We would like to express our heartfelt thanks to Addis Ababa University, Department of Biology for lab facilities and cooperation. We would express our gratitude to Dr Amare Gessesse for his support on enzyme assay work. We also thank Animal Nutrition Research staff, Holetta Research Centre, EIAR for their material and financial support.

\section{REFERENCES}

1. Akin, D. and Borneman, W. (1990). Role of rumen fungi in fibre degradation. J. Dairy Sci. 73:30233032.

2. Alexopoulus, C.J. and Beneke, E.S. (1968). Laboratory Manual for Introductory Mycology. Burgess Publishing Company, Minneapolis, 199 pp.

3. Amare Gessesse and Berhanu Gashe (1997). Production of alkaline protease by an alkaliphilic bacteria isolated from an alkaline soda lake. Biotechnology Letter 19(5):479-481.

4. Amare Gessesse, Rajni, H.K., Berhanu Gashe and Mattiasson, B. (2003). Novel alkaline Protease from alkaliphilic bacteria grown on chicken feather. Enz Micro Technology 32:519-524.

5. Bergey, D.H. (1984). Bergey's Manual of Systematic Bacteriology. (Sneath, A.H.P., Mair, S.N., Sharpe, E.M. and Holt G.J., eds). Willians and Wilkins, Batimne, USA.

6. Bhat, S., Wallace, R.J. and Orskov, E.R. (1990). Adhesion of cellulolytic ruminal bacteria to barely straw. Appli. Environ. Microbiol. 56(9): 2698-2703.

7. Chenost, M. and Sansoucy, R. (1998). Nutritional characteristics of tropical feed resources. Natural and improved grasslands, crop residues and agro industrial byproducts. In: Feeding Dairy Cows in the Tropics (Andrew, S. and Rene, S. eds). FAO, Rome, $245 \mathrm{pp}$.

8. Chesworth, J.C. (2004). The Tropical Agriculturalist. Ruminant Nutrition. CTA, Macmillan, $170 \mathrm{pp}$.

9. Duncan, W.R., Orkov, E.R., Frazer, C. and Garton, G.A. (1974). Effect of processing of dietary barely and supplementary cobalt and Cyanocobalamine on the fatty acid composition of lamb tryglyceride with special reference to branched chain fatty acids. Journal of Nutrition 32:71-75.

10. Eden Efrem (2002). Isolation and characterization of tannin and gallic acid degrading bacteria from indigenous Ethiopian wild and adapted ruminants. MSc thesis, Department of Biology, AAU, Ethiopia, 57 pp.

11. FAO/IAEA (1989). Analytical Techniques for Characterizing Ruminant Feedstuffs. Agri. Lab., Animal Production and Health Unit. Seibersdorf, Austria, $52 \mathrm{pp}$.

12. Findlay, A. (1998). Microbiology of the Rumen and Small and Large Intestines. Physiological Laboratory, University of Cambridge. Internet: http://www.chu.cam.ac.uk/ ALRF/micrbiol. $\mathrm{htm}$. Accessed on 13 $3^{\text {th }}$ October 2007.

13. Garrett, J. (2000). Use Yeast Culture to "Feed the Rumen First" Feed Management. 
Interent:http://www.diamondv.com/articles/ feed_the_rumen_first.htm Accessed on 13th October 2007.

14. Garry, S.K. (1987). Small Scale Fattening. In: Proceedings of the 1st Livestock Improvement Conference. 11-13 Feb. Addis Ababa, Ethiopia.

15. Getnet Assefa, Fekede Feyissa and Abreham Gebeyehu (2003). Effect of manure and fertilization on establishment, herbage yield and seed productivity of perennial grasses. In: Challenges and Opportunities of Livestock Marketing in Ethiopia. 10th Annual Conference of ESAP 21-23 August. pp 245-255.

16. Gordon, J., Perez-Barberia, J. and William, N. (2002). The influence of adaptation of rumen microflora on in vitro digestion of different forages by sheep and red deer. Can. J. Zool. 80(11):1930-1937.

17. Jamieson, A., Pruitt, K. and Caldwell, R. (1968). An Improved Amylase Assay. Institute of Dental Research and Laboratory of Molecular Biology, University of Alabama Medical Centre, 483 PP.

18. Joblin, K., Naylor, G. and Williams, R. (1990). Effect of Methanobravibacter smithii on xylanolytic activity of anaerobic rumen fungi. Appli. Environ. Microbiol 56(8):2287-2295.

19. Misrak Kebede (2000). Isolation and Characterization of bacteria tolerant to toxic Compounds in Acacia angustissima leaves, from free ranging sheep and goats. MSc thesis Department of Biology, AAU, Ethiopia, 54 pp.

20. Moharrery, A, and Das, T. (2001). Correlation between microbial enzyme activities in the rumen fluid of sheep under different treatments. Reprod Nutr Dev. 41(6):513-529.

21. Njoya, A. (1996). Protein supplementation of grazing cattle in semi-arid zone of Cameroon. In: Sustainable Feed Production and Utilization for Small Holder Livestock Enterprise in Sub-saharan Africa (Ndikumana J. and Leeuw P. eds). Proceeding of the 2nd African Feed Resource Network (AFRNET) workshop, 6-10 December 1993, Harare, Zimbabwe.

22. Odenyo, A, Osuji, O. and Kranfil, O. (1997). Effect of multipurpose tree supplements on ruminal ciliate protozoa. Animal Feed Sci. and Techno. 67:169-180.

23. Odenyo, A.A., McSweeney, C. S., Palmal, B., Negessa, D. and Osuji, P.O. (1999). In Vitro screening of rumen fluid samples from indigenous African ruminants provides evidences for rumen for rumen fluid with superior capacities to digest tannin-rich fodders. Australian J. Agricultural Researches 50:1147-1157.
24. Orskov, E.R. and Rye, M. (1990). Energy Nutrition in Ruminants. Elsevier Applied Sciences, London and New York, 149 pp.

25. Paul, S. and Kamara, N. (2004). Effect of anaerobic on invitro feed digestion by mixed rumen microflora of buffalo. Reprod. Nutr. Dev. 44:313319.

26. Seyoum Bediye, Dereje Fekadu and Aemiro Kehaliwu (2004). A Training Manual on Recent Development in Animal feeds and nutrition. Ethiopian Institute of Agricultural Research. 10-11 May Holleta Research Centre, Ethiopia, $35 \mathrm{pp}$.

27. Seyoum Bediye, Zinash Sileshi and Dereje Fekadu (2007). Chemical composition and Nutritive value of Ethiopian Feeds. EIAR, Research Report (73) 27.

28. Tesfaye Wondimu, Osuji, P., Asfaw Yigezu and Alemu Yami (2001). Effect of wheat bran supplementation on feed intake, bodyweight change and retained energy in carcass of Ethiopian highland zebu cattle fed tef straw as a basal diet. In: Livestock in Food Security, Roles and Contributions, pp. 111-124. Ninth annual conference of ESAP, 30-31 Aug, Addis Ababa, Ethiopia.

29. Tilley, J. and Terry. (1963). A two stage technique for in-vitro digestion of forage crops. J.Br. Grassl. Soc. 18:104.

30. Vansoest, P.J. (1982). Nutritional Ecology of the ruminants. Remnant Metabolism Nutritional Strategies, the Cellulolytic Fermentation and the Chemistry of Forages and Plant Fibres. Comstrock Publishing Association a Division of Cornell university Press, Ithaca and London, $373 \mathrm{pp}$.

31. Varvikko, J. and Khalilli, H. (1993). Wilted tagasate (tree lucern) forage as a replacement for a concentrate for lactating crossbred Freisian $X$ Zebu (Boran) dairy cows fed low quality native hay. Anim. Feed Sci. And Techno. 40:239-250.

32. Wahlberg, M. (1999). Supplementing Forages with Grain. 4-H Livestock, Animal and Poultry Sciences. Virginia Tech., USA, 174 pp.

33. Wallace, K. (1994). Influence of Yucca shidigera extract on ruminal ammonia concentration and ruminal microorganisms. Appl. Environ. Microbiol 60:1762-1767.

34. Wina, E., Muetze, S. and Becker, K. (2006). The dynamics of major fibrolytic microbes and enzyme activity in the rumen in response to short- and long-term feeding of Sapindus rarak saponins. J. Appl. Microbio.100 (1):114. 